\title{
The Inter-Regional Epidemiological Study of Childhood Cancer (IRESCC): past medical history in children with cancer
}

\begin{abstract}
A L HARTLEY, ${ }^{1} \mathrm{~J}^{\mathrm{M}}$ BIRCH, $^{1}$ P A M $^{\mathrm{c}} \mathrm{KINNEY,}{ }^{2}$ V BLAIR, ${ }^{1}$ M D TEARE, ${ }^{1}$ J CARRETTE, ${ }^{2}$ J R MANN, ${ }^{3}$ C A STILLER, ${ }^{4}$ G J DRAPER, ${ }^{4}$ H E JOHNSTON, ${ }^{5}$ R A CARTWRIGHT, ${ }^{2}$ AND J A H WATERHOUSE ${ }^{5}$

From the Department of Epidemiology and Social Oncology, Christie Hospital \& Holt Radium Institute, ${ }^{1}$ Manchester M20 9BX; the Leukaemia Research Fund Centre for Clinical Epidemiology, University of Leeds, ${ }^{2}$ Department of Pathology, 17 Springfield Mount, Leeds LS2 9NG; The Children's Hospital, ${ }^{3}$ Ladywood Middleway, Ladywood, Birmingham B16 8ET; the Childhood Cancer Research Group, ${ }^{4}$ Radcliffe Infirmary, Oxford OX2 6HE; and the West Midlands Cancer Registry, ${ }^{5}$ Queen Elizabeth Medical Centre, Birmingham B16 $8 E T$.
\end{abstract}

The IRESCC Group consists of the authors and DR C C BAILEY, DR A H CAMERON, DR R H A CAMPBELL, DR S C CARTWRIGHT, MR J J CORKERY, DR D DEAKIN, MR P GORNALL, MR P A HOPTON, PROFESSOR H B MARSDEN, DR P H MORRIS-JONES, DR D PEARSON, MISS J M T SAIU, MR R SWINDELL, AND MRS J WILLIAMS

SUMmARY The Inter-Regional Epidemiological Study of Childhood Cancer (IRESCC) collected interview and medical information relating to the child's past medical experiences from parents of 555 children diagnosed with cancer and parents of 1110 unaffected matched controls. No significant associations emerged overall for ante-natal care, place and mode of delivery, length of gestation, birth weight, condition at birth, special care, neonatal procedures or breast-feeding. Few risk factors relating to previous illnesses and medication were found, although increasing numbers of illnesses appeared to be associated with an increased risk of childhood cancer, particularly acute lymphoblastic leukaemia. A highly significant excess of case children had not been immunised $(p=0.005)$. In general, these results indicate that past medical experiences have little influence on the development of cancer in children.

No major aetiological factors have been implicated in the development of childhood cancer. Because of the early onset and embryonal nature of most childhood tumours, investigations have focussed on the antenatal period as the time when any extrinsic factors, eg chemical exposures, may be effective in initiating tumour formation in the developing foetus. Indeed some degree of risk has been demonstrated for exposure to $\mathrm{X}$-irradiation in pregnancy ${ }^{12}$ and reports have suggested transplacental carcinogenesis caused by drugs taken during pregnancy. ${ }^{3-5}$ Other studies have implicated certain parental occupations in the development of childhood cancer but evidence on this is conflicting. ${ }^{6}$

Indications of an important role for genetic factors in the aetiology of childhood cancer have been accumulating ${ }^{7}$ but the presence of genetic susceptibility does not necessarily imply that a child will develop cancer, and additional environmental factors may be needed to induce malignancy in a particular individual.

Some associations between post-natal medical events and specific types of childhood cancer have been demonstrated. For example Burkitt's lymphoma develops under special circumstances after infection with Epstein-Barr virus. ${ }^{8}$ A case-control study of children with leukaemia showed a lower frequency of infections among cases in the first year of $\operatorname{life}^{9}$ and tonsillectomy has been reported as a risk factor for Hodgkin's disease. ${ }^{10}$

The Inter-Regional Epidemiological Study of Childhood Cancer (IRESCC) collected data relating to the child's past medical experiences from the parents of 555 children diagnosed with childhood cancer and the parents of 1110 unaffected matched controls. This paper evaluates various perinatal and 
postnatal events in the life of the child as risk factors for the development of childhood cancer.

\section{Methods}

Cases (C) of childhood malignancy (under 15 years) and of certain benign and borderline neoplastic conditions diagnosed between January 1980 and January 1983 in the North Western, West Midlands and Yorkshire Regional Health Authorities were included in the study. A description of the methodology for IRESCC has been published elswhere. ${ }^{11}$ Interviews were carried out with the parents of a representative sample of 555 such children and with parents of 1110 age- and sex-matched control children. One set of 555 controls was chosen from each case child's current general practitioner's listing (GPC), and a second set of controls from among children admitted to hospital at the same time as the case child for acute illnesses or accidents (HC). The interview was conducted using a standard questionnaire and covered events during the index pregnancy, past medical history of the index child, parents, siblings and other family members, together with parental occupations and smoking history.

Medical confirmation of the index child's malformations, serious and chronic illness and longterm medication was sought from general practitioner and hospital records. The mother's obstetric notes for the relevant pregnancy were routinely obtained.

Up to six illnesses in the index child were coded using the International Classification of Diseases (ICD9). ${ }^{12}$ Common named infectious diseases of childhood, ie chickenpox, measles, rubella, mumps and scarlet fever, were not coded unless they occurred under 6 months of age. Neonatal events and illnesses were not coded for cases and controls where the case child was diagnosed with a tumour under one month of age.

Risk factors examined in this analysis include length of gestation, place and type of delivery, birthweight, condition at birth, and neonatal events, for example phototherapy, exchange transfusion and breastfeeding. Illnesses reported in children under and over 6 months, but excluding those suffered by the case child during the onset period and after diagnosis, were examined by ICD9 chapter. Case-control comparisons were made for infectious and parasitic diseases (ICD9 001-139), endocrine, nutritional and metabolic diseases, and immunity disorders (240279), diseases of blood and blood-forming organs (280-289), mental disorders (290-319), diseases of the nervous system and sense organs (320-389), circulatory system (390-459), respiratory system (460$519)$, digestive system (520-579), genito-urinary system (580-629), skin and subcutaneous tissue (680709), musculoskeletal system and connective tissue (710-739), conditions originating in the perinatal period (760-779) and symptoms, signs and ill-defined conditions (780-799). Comparisons were also made by more specific illness groups within ICD9 chapters and by individual illness codes where numbers permitted. Congenital malformations in the index children (ICD9 740-759) were not included in this analysis and will be reported elsewhere.

Drug ingestion was compared for three periods in the child's life: in the first month, from 1 to 5 months, and 6 months and over. Drugs were classified as antibiotics, anticonvulsants, corticosteroids, antiallergic, bronchospasm relaxants, sedatives, decongestants, cough suppressants and expectorants, and drugs for gastrointestinal disorders. Past history of therapeutic irradiation and immunisation was also examined. The majority of these analyses relate only to information given at interview.

\section{STATISTICAL ANALYSES}

Case-control comparisons were made initially using tables produced by SPSS version $\mathrm{X}^{13}$ and statistical analyses undertaken using routines supplied by EPILOG version 2.0 (Epicenter Software, PO Box 90073, Pasadena, CA 91109, USA). The analyses of cases versus pooled controls was carried out using $\chi^{2}$ and Fisher's exact test for categorical variables. The Mann-Whitney $U$ test and the Kruskall Wallis procedure were employed to compare non-normal distributions. Relative risks were estimated by the Mantel-Haenzel method (stratification by diagnostic group was carried out where possible); tests for trend and homogeneity were those recommended by Breslow \& Day. ${ }^{14}$

\section{Results}

Distribution by sex and diagnosis of the 555 cases together with median age at diagnosis are shown in table 1 .

BIRTH EVENTS, NEONATAL CONDITION AND EXPERIENCES

A summary of these results for all cases combined is shown in table 2 . Almost $90 \%$ of mothers had their antenatal care at a hospital clinic. Six mothers reported no antenatal care and the remaining $10 \%$ were seen solely by their general practitioners. Similarly the majority $(93 \%)$ of births took place in hospital. Nearly $80 \%$ of babies were born by normal vertex or breech delivery, $12 \%$ by forceps or ventouse and the rest by Caesarean section. Overall there were no significant differences between cases and controls in antenatal care, place of birth and mode of delivery. 
Table 1 Index cases

\begin{tabular}{|c|c|c|c|c|c|}
\hline Diagnosis & Male & Female & Total & $\%$ & $\begin{array}{l}\text { Median age } \\
\text { at diagnosis } \\
\text { (months) }\end{array}$ \\
\hline Acute lymphoblastic leukaemia & 80 & 68 & 148 & $26 \cdot 7$ & 64 \\
\hline Other leukaemia & 12 & 11 & 23 & $4 \cdot 1$ & 78 \\
\hline Hodgkin's disease & 25 & 7 & 32 & $5 \cdot 8$ & 132 \\
\hline Non-Hodgkin's lymphoma & 22 & 9 & 31 & $5 \cdot 6$ & 102 \\
\hline Central nervous system tumours & 50 & 28 & 78 & $14 \cdot 0$ & 94 \\
\hline Soft tissue sarcoma & 27 & 16 & 43 & $7 \cdot 7$ & 81 \\
\hline Bone tumours & 14 & 16 & 30 & 5.4 & 144 \\
\hline Wilms' tumour & 11 & 21 & 32 & $5 \cdot 8$ & 33 \\
\hline Neuroblastoma & 16 & 19 & 35 & $6 \cdot 3$ & 13 \\
\hline Retinoblastoma & 4 & 2 & 6 & $1 \cdot 1$ & 23 \\
\hline Hepatoblastoma & 3 & 3 & 6 & $1 \cdot 1$ & 16 \\
\hline Germ cell tumours & 15 & 26 & 41 & $7 \cdot 4$ & 31 \\
\hline Epithelial tumours & 9 & 13 & 22 & $4 \cdot 0$ & 129 \\
\hline Other malignant and benign tumours & 14 & 14 & 28 & $5 \cdot 0$ & 29 \\
\hline Total & 302 & 253 & 555 & $100 \cdot 0$ & 71 \\
\hline
\end{tabular}

Table 2 Birth events, neonatal condition and experiences. All cases combined

\begin{tabular}{|c|c|c|c|c|c|c|c|}
\hline & & \multicolumn{3}{|c|}{ Numbers } & \multirow{2}{*}{$\begin{array}{l}\text { Relative } \\
\text { risk }\end{array}$} & \multirow{2}{*}{$\begin{array}{l}95 \% \text { confidence } \\
\text { interval }\end{array}$} & \multirow[b]{2}{*}{ p value } \\
\hline & & $C^{*}$ & $G P C+$ & $H C t$ & & & \\
\hline $\begin{array}{l}\text { Antenatal care } \\
\text { GP or none } \\
\text { Hospital }\end{array}$ & & $\begin{array}{r}60 \\
495\end{array}$ & $\begin{array}{r}61 \\
494\end{array}$ & $\begin{array}{r}52 \\
502\end{array}$ & 1.06 & $0.75-1 \cdot 50$ & 0.80 \\
\hline $\begin{array}{l}\text { Place of birth } \\
\text { Home or other } \\
\text { Hospital }\end{array}$ & & $\begin{array}{r}40 \\
513\end{array}$ & $\begin{array}{r}35 \\
519\end{array}$ & $\begin{array}{r}36 \\
517\end{array}$ & $1 \cdot 14$ & $0.74-1.75$ & 0.60 \\
\hline $\begin{array}{l}\text { Mode of delivery } \\
\text { Assisted } \\
\text { Normal }\end{array}$ & & $\begin{array}{r}96 \\
440\end{array}$ & $\begin{array}{r}97 \\
451\end{array}$ & $\begin{array}{l}140 \\
409\end{array}$ & 0.79 & $0.6-1.04$ & 0.09 \\
\hline $\begin{array}{l}\text { Apgar score } \\
\text { Poor } \\
\text { Satisfactory/good }\end{array}$ & & $\begin{array}{r}31 \\
367\end{array}$ & $\begin{array}{r}19 \\
391\end{array}$ & $\begin{array}{r}27 \\
384\end{array}$ & 1.40 & $0.88-2 \cdot 22$ & $0 \cdot 19$ \\
\hline $\begin{array}{l}\text { Special Care Baby Uni } \\
\text { Reported }\end{array}$ & $\begin{array}{l}\text { Yes } \\
\text { No }\end{array}$ & $\begin{array}{r}76 \\
432\end{array}$ & $\begin{array}{r}57 \\
455\end{array}$ & $\begin{array}{r}82 \\
427\end{array}$ & $1 \cdot 12$ & $0.82-1.54$ & 0.51 \\
\hline Medically recorded & $\begin{array}{l}\text { Yes } \\
\text { No }\end{array}$ & $\begin{array}{r}55 \\
413\end{array}$ & $\begin{array}{r}37 \\
426\end{array}$ & $\begin{array}{r}59 \\
409\end{array}$ & $1 \cdot 17$ & $0.81-1 \cdot 70$ & 0.43 \\
\hline $\begin{array}{l}\text { Phototherapy }{ }^{1} \\
\text { Reported }\end{array}$ & Yes & 16 & 18 & 9 & $1 \cdot 19$ & $0.61-2.32$ & 0.70 \\
\hline Medically recorded & $\begin{array}{l}\text { No } \\
\text { Yes } \\
\text { No }\end{array}$ & $\begin{array}{r}520 \\
17 \\
451\end{array}$ & $\begin{array}{r}518 \\
19 \\
449\end{array}$ & $\begin{array}{r}526 \\
18 \\
446\end{array}$ & 0.93 & $0.49-1.74$ & 0.93 \\
\hline Exchange transfusion ${ }^{1}$ & & & & & & & \\
\hline Reported & $\begin{array}{l}\text { Yes } \\
\text { No }\end{array}$ & $\begin{array}{r}2 \\
552\end{array}$ & $\begin{array}{r}2 \\
552\end{array}$ & $\begin{array}{r}0 \\
553\end{array}$ & $-{ }^{n}$ & - & - \\
\hline Medically recorded & $\begin{array}{l}\text { Yes } \\
\text { No }\end{array}$ & $\begin{array}{r}2 \\
483\end{array}$ & $\begin{array}{r}2 \\
481\end{array}$ & $\begin{array}{r}0 \\
486\end{array}$ & $-n$ & - & - \\
\hline General anaesthetic ${ }^{1}$ & & & & & & & \\
\hline Reported & $\begin{array}{l}\text { Yes } \\
\text { No }\end{array}$ & $\begin{array}{r}3 \\
550\end{array}$ & $\begin{array}{r}0 \\
552\end{array}$ & $\begin{array}{r}2 \\
550\end{array}$ & $-{ }^{n}$ & - & - \\
\hline Medically recorded & $\begin{array}{l}\text { Yes } \\
\text { No }\end{array}$ & $\begin{array}{r}1 \\
481\end{array}$ & $\begin{array}{r}1 \\
480\end{array}$ & $\begin{array}{r}1 \\
483\end{array}$ & $-\mathbf{n}$ & - & - \\
\hline Neonatal X-ray 1 & & & & & & & \\
\hline Reported & $\begin{array}{l}\text { Yes } \\
\text { No }\end{array}$ & $\begin{array}{r}3 \\
532\end{array}$ & $\begin{array}{r}1 \\
533\end{array}$ & $\begin{array}{r}2 \\
532\end{array}$ & $2.00^{3}$ & $0 \cdot 32-12 \cdot 51$ & 0.67 \\
\hline Medically recorded & $\begin{array}{l}\text { Yes } \\
\text { No }\end{array}$ & $\begin{array}{r}5 \\
460\end{array}$ & $\begin{array}{r}4 \\
459\end{array}$ & $\begin{array}{r}5 \\
460\end{array}$ & $1 \cdot 11^{3}$ & $0.32-3.63$ & 0.92 \\
\hline $\begin{array}{c}\text { Breast-feeding }{ }^{2} \\
\text { Breast-fed }\end{array}$ & $\begin{array}{l}\text { Yes } \\
\text { No }\end{array}$ & $\begin{array}{l}230 \\
290\end{array}$ & $\begin{array}{l}245 \\
281\end{array}$ & $\begin{array}{l}219 \\
305\end{array}$ & 1.00 & $0.80-1 \cdot 24$ & 0.97 \\
\hline
\end{tabular}

* Cases; $\uparrow$ General Practitioner controls; $¥$ Hospital controls; ${ }^{1}$ Excluding cases with congenital tumours; ${ }^{2}$ Excluding cases diagnosed under 3 months; ${ }^{3}$ Not stratified by diagnostic group because of small numbers; ${ }^{n}$ Numbers insufficient for analysis. All groups have one or more missing values. 
Within individual diagnostic groups there were significantly fewer assisted deliveries among children with bone tumours compared with their controls $(1 \mathrm{C}$, 7 GPC, $6 \mathrm{HC}$; relative risk $(\mathrm{RR})=0 \cdot 12,95 \%$ confidence interval (CI) 0.00-0.93, p = 0.04.

Mean length of gestation for all cases combined was 39.8 weeks and for their pooled controls 39.7 weeks. Comparison between means for all cases combined and for each diagnostic group and their respective controls revealed no significant results other than the finding that children with germ cell tumours had a longer period of gestation than their controls (cases 40.4 weeks, controls 39.7 weeks, $p=0.03$, Mann Whitney U-test).

Reported and medically recorded birth weights were remarkably consistent and there were no significant differences between cases and controls overall. Mean birth weight for all cases combined was $3324 \mathrm{~g}$ (reported), $3304 \mathrm{~g}$ (medically recorded). Children with bone tumours, however, were reported lighter than their controls (cases $3147 \mathrm{~g}$, controls $3361 \mathrm{~g}, \mathrm{p}=0.03$, Mann Whitney $U$ test) and this was borne out by medically recorded data (cases $3072 \mathrm{~g}$, controls $3356 \mathrm{~g}, \mathrm{p}=0.07$ ). The higher proportion of normal deliveries in this group may be linked with this finding. On the other hand, children with germ cell tumours had a significantly higher mean birth weight than their controls (cases $3524 \mathrm{~g}$, controls $3254 \mathrm{~g}$, $\mathrm{p}=0.008$, reported; cases $3493 \mathrm{~g}$, controls $3264 \mathrm{~g}$, $\mathrm{p}=0.03$, medically recorded). This finding may be a consequence of their overall longer period of gestation.

Condition at birth was coded only from medically recorded data. Babies with an Apgar score of 5 or less at 1 minute were considered to be in poor condition and those with a score of 6-10 to be in a satisfactory/ good condition. Information was available for $73 \%$ of children and there was no significant case control difference overall. Special care after birth was defined as referral to a special care baby unit or more than 24 hours spent in an incubator. This and other variables relating to the perinatal period, ie phototherapy for jaundice, exchange transfusion for rhesus incompatibility, diagnostic X-ray and general anaesthetic, were also analysed for reported and medically recorded data. No significant case-control differences emerged. Numbers were too small to permit statistical analysis by diagnostic group.

Breast-feeding was thought unlikely to be a risk factor for children diagnosed with their tumour under 3 months of age and these children were eliminated from the analysis. Of the remaining 528 cases and their controls, fewer than half $(44 \%)$ had been breast-fed and there was no evidence that breast-feeding conferred any protection against developing childhood cancer.

Table 3 Illnesses reported at interview associated with childhood cancer

\begin{tabular}{|c|c|c|c|c|c|c|c|}
\hline \multirow{2}{*}{$\begin{array}{l}\text { Condition (ICD9 chapter, } \\
\text { illness group or specific } \\
\text { illness) }\end{array}$} & \multirow[b]{2}{*}{$\begin{array}{l}\text { Diagnostic group } \\
\text { (no of cases) }\end{array}$} & \multicolumn{3}{|c|}{ Numbers } & \multirow[b]{2}{*}{$\begin{array}{l}\text { Relative } \\
\text { risk }\end{array}$} & \multirow[b]{2}{*}{$\begin{array}{l}95 \% \text { confidence } \\
\text { interval }\end{array}$} & \multirow[b]{2}{*}{$p$ value } \\
\hline & & $C^{*}$ & GPC & $H C t$ & & & \\
\hline $\begin{array}{l}\text { IInesses under } 6 \text { months } 1 \\
\text { Diseases of the nervous } \\
\text { system and sense organs } \\
(320-389)\end{array}$ & $\begin{array}{l}\text { Bone tumours } \\
\text { (30) }\end{array}$ & 0 & 4 & 6 & - & - & 0.03 \\
\hline $\begin{array}{l}\text { Perinatal conditions } \\
(760-779)\end{array}$ & $\begin{array}{l}\text { Germ cell tumours } \\
\text { (31) }\end{array}$ & 13 & 6 & 2 & $4 \cdot 88$ & $1.56-15.61$ & 0.004 \\
\hline $\begin{array}{l}\text { Infections specific to the } \\
\text { perinatal period } \\
(771.0-771.9)\end{array}$ & $\begin{array}{l}\text { Acute lymphoblastic } \\
\text { leukaemia } \\
\text { (148) }\end{array}$ & 5 & 1 & 0 & 10.31 & $1.8-59.26$ & 0.03 \\
\hline $\begin{array}{l}\text { Other perinatal jaundice } \\
(774.0-774.9)\end{array}$ & $\begin{array}{l}\text { Hepatoblastoma } \\
\text { (6) }\end{array}$ & 3 & 0 & 0 & - & - & 0.05 \\
\hline $\begin{array}{l}\text { Other perinatal conditions } \\
(779.0-779.9)\end{array}$ & $\begin{array}{l}\text { Germ cell tumours } \\
\text { (31) }\end{array}$ & 4 & 0 & 0 & - & - & 0.02 \\
\hline $\begin{array}{l}\text { Unspecified foetal and } \\
\text { neonatal jaundice } \\
\text { (774.6) }\end{array}$ & $\begin{array}{l}\text { Hepatoblastoma } \\
\text { (6)) }\end{array}$ & 3 & 0 & 0 & - & - & 0.05 \\
\hline $\begin{array}{l}\text { Illnesses over } 6 \text { months } 2 \\
\text { Allergic rhinitis } \\
(477.0-477.9)\end{array}$ & $\begin{array}{l}\text { Non-Hodgkin's lymphona } \\
\text { (31) }\end{array}$ & 0 & 7 & 2 & - & - & 0.04 \\
\hline $\begin{array}{l}\text { Contact dermatitis and } \\
\text { other eczema } \\
(692.0-692.9)\end{array}$ & $\begin{array}{l}\text { All cases combined } \\
(521)\end{array}$ & 21 & 29 & 44 & 0.56 & $0.33-0.94$ & 0.03 \\
\hline $\begin{array}{l}\text { Contact dermatitis and } \\
\text { other eczema, unspecified } \\
\text { (692.9) }\end{array}$ & $\begin{array}{l}\text { All cases combined } \\
(521)\end{array}$ & 19 & 28 & 42 & 0.53 & $0.30-0.90$ & 0.02 \\
\hline
\end{tabular}

* Cases; $\uparrow$ General Practitioner controls; $¥$ Hospital controls; ${ }^{1}$ Excluding cases with congenital tumours; ${ }^{2}$ Excluding cases diagnosed under 6 months; ( $\rightarrow$ ) Relative risk not calculated because number of cases or controls zero. 


\section{L L NESSES}

Relative risks were calculated for all cases and for certain diagnostic groups for episodes of illness classified by ICD 9 chapter, by illness group within ICD9 chapter, and by individual ICD9 illness codes. These analyses were undertaken separately for conditions occurring before or after 6 months and were restricted to variables where a minimum of $5 \%$ (for ICD9 chapter) and 1\% (for illness group within ICD9 chapter or individual ICD9 illnesses code) of cases and controls had positive responses. The large number of illness groups (approximately 250) and individual illness codes (approximately 350 ) reported or confirmed for the study resulted in few cases falling into each category. Calculations were thus only possible for all cases combined except for a limited number of disease categories in certain diagnostic groups. In addition cases and controls were compared for the total number of illnesses reported.

Comparisons of reported illnesses resulting in statistically significant relative risks, excluding ICD9 chapter 16 (symptoms, signs and ill-defined conditions) are shown in table 3 . All cases combined were reported as having a highly significant excess of symptoms, signs and ill-defined conditions over 6 months of age (ICD9 780-799; 93 C, $63 \mathrm{GPC}, 57 \mathrm{HC}$; $R R=1 \cdot 67,95 \%$ CI $1 \cdot 23-2 \cdot 26, p=0.0008)$. Cases were more often reported as having symptoms involving skin, eg rash, swellings, oedema, jaundice, or nutrition and development, eg anorexia, abnormal weight gain or loss, feeding problems.

For medically confirmed conditions no significant relative risk emerged for any ICD9 illness chapter, group or specific illness for children aged under or over 6 months, for all cases combined or for any diagnostic group, except that the total group had an excess of repeated acute upper respiratory tract infections over 6 months of age (ICD9 465.0-465.9; $18 \mathrm{C}, 10 \mathrm{GPC}, 6 \mathrm{HC}$; RR $=2 \cdot 29,95 \%$ CI $1 \cdot 11-4 \cdot 77$, $\mathrm{p}=0.02)$.
For all cases combined increasing numbers of illnesses over 6 months were associated with an increased risk of childhood cancer $(p=0.05)$. This trend was particularly apparent for children with acute lymphoblastic leukaemia (ALL) $(p=0.004)$. A similar association emerged for increasing numbers of illnesses under 6 months in children with germ cell tumours $(p=0.003)$ (table 4).

\section{MEDICATION}

All drugs reported as being given within the first month of life were coded but subsequent coding included only those taken for a total of $\mathbf{3 0}$ or more days in any 6-month period. Medical data were available for neonatal drugs and for prolonged medication taken over 6 months of age. Relative risks were calculated for exposure to each of the nine drug groups. Analyses were carried out for drugs taken in the first month, between 1 and 5 months and 6 months and over, and were restricted to drug groups where a minimum of $1 \%$ of cases and controls were reported as having received a particular type of medication. Case-control comparisons were also made for total numbers of drugs received.

Only one significant difference emerged from a total of 675 comparisons. Children with soft tissue sarcoma had more medically recorded reports of having received antibiotics in the neonatal period than their controls $(6 \mathrm{C}, 1 \mathrm{GPC}, 1 \mathrm{HC}$; RR $=6.81,95 \% \mathrm{CI}$ $1 \cdot 13-71 \cdot 18, p=0.03)$. Total numbers of drugs reported and medically recorded were remarkably uniform, and evidence of any trend associated with increased use of medication by cases at any time was lacking. Children with germ cell tumours had fewer medically recorded drugs of any kind during the neonatal period $(p=0.04)$ as did children with Non-Hodgkin's lymphoma over 6 months $(p=0.05)$.

PREVIOUS IRRADIATION TREATMENT

Previous irradiation treatment was reported for two

Table 4 Relationship between cancers and number of childhood illnesses

\begin{tabular}{|c|c|c|c|c|c|c|c|}
\hline \multirow{2}{*}{$\begin{array}{l}\text { Index child } \\
\text { (number of cases) }\end{array}$} & & \multicolumn{5}{|c|}{ Total number of illnesses } & \multirow{2}{*}{$\begin{array}{l}p \text { value } \\
\text { for trend }\end{array}$} \\
\hline & & 0 & $l$ & 2 & 3 & 4 or more & \\
\hline \multirow{4}{*}{$\begin{array}{l}\text { Under } 6 \text { months } \\
\text { Germ cell tumours } \\
(31)^{1}\end{array}$} & & & & & & & \\
\hline & $C^{*}$ & 8 & 15 & 5 & 2 & 1 & \\
\hline & GPC† & 18 & 10 & 3 & 0 & 0 & 0.003 \\
\hline & $\mathrm{HC} \neq$ & 19 & 7 & 5 & 0 & 0 & \\
\hline \multirow{4}{*}{$\begin{array}{l}\text { Over } 6 \text { months } \\
\text { All cases combined } 2 \\
(521)^{3}\end{array}$} & & & & & & & \\
\hline & C & 183 & 160 & 97 & 50 & 31 & \\
\hline & GPC & 198 & 174 & 90 & 29 & 30 & 0.05 \\
\hline & $\mathrm{HC}$ & 220 & 141 & 87 & 40 & 33 & \\
\hline \multirow{3}{*}{$\begin{array}{l}\text { Acute lymphoblastic } \\
\text { leukaemia }(146)^{3}\end{array}$} & $\mathrm{C}$ & 50 & 37 & 32 & 16 & 11 & \\
\hline & GPC & 61 & 53 & 19 & 6 & 7 & 0.004 \\
\hline & HC & 64 & 42 & 23 & 9 & 8 & \\
\hline
\end{tabular}
* Cases; $†$ General Practitioner controls; $\neq$ Hospital controls; ${ }^{1}$ Excluding cases with congenital tumours; ${ }^{2}$ Stratified by diagnostic group; ${ }^{3}$ Excluding cases diagnosed
under 6 months. 
children. One hospital control was exposed to thorium contrast over two years as treatment for a capillary haemangioma, and a case child age 6 years with a pineal tumour had previously received radiotherapy for bilateral retinoblastoma when aged 7 months. This child's tumour had not been biopsied but was diagnosed as an ectopic intracranial retinoblastoma and has been described by Bader et al. ${ }^{15}$

\section{IMMUNIS ATIONS}

Immunisation against tetanus, diphtheria, whooping cough, poliomyelitis, measles, smallpox and rubella was noted at interview but precise dates of immunisation and confirmation from medical records were not available. Children under 2 years of age at diagnosis were excluded from the analysis because in this age group symptoms preceding the onset of the tumour may have led to immunisation not being carried out. Of the 439 children remaining, those who had never been immunised were at significantly higher risk of developing childhood cancer compared with children who had received one or more of the standard vaccines $(14 \mathrm{C}, 1 \mathrm{GPC}, 7 \mathrm{HC} ; \mathrm{RR}=3.58,95 \% \mathrm{CI}$ $1 \cdot 57-8 \cdot 15, p=0.005)$. Unimmunised case children were not confined to any diagnostic group and where an explanation for non-immunisation had been given at interview, no consistent reason was put forward. Contra-indications in three children were frequent coughs and colds in infancy and in another child chronic diarrhoea. One mother had been advised against immunisation because of "family reactions" and three families were opposed in principle to the procedure.

\section{Discussion}

The 555 cases interviewed for the IRESCC study formed a representative sample of cases of childhood cancer, although central nervous system tumours were relatively under-represented. The present study should identify general risk factors for childhood cancer while analysis by diagnostic group might point to more specific risk factors.

Birth events and neonatal experiences appeared to have little influence on the child's risk of developing a malignancy. While several studies have reported that higher birth weight is associated with death from childhood cancer, ${ }^{16}{ }^{17}$ the results of our investigation tend to lend support to a more recent report that birth weight is not an important predictor of childhood cancer risk. ${ }^{18}$ This latter study, however, like most others in this field, examined deaths rather than incident cases of childhood cancer and hence is not strictly comparable with the results reported here.

There was some evidence that for all cases combined increasing numbers of reported illnesses over the age of 6 months were associated with an increased risk of childhood cancer. This effect was particularly apparent for children with ALL, and a more detailed analysis of this association is presented elsewhere. ${ }^{19}$ In spite of extensive comparisons of illness groups and individual illnesses by diagnostic group within IRESCC (potentially over 10000 comparisons were possible, although small numbers precluded more than about 200 calculations being carried out) no systematic pattern of risk factors in the child's past history of illness has emerged. Indeed very few significant results involving more than a tiny proportion of cases in each group were found (and at least as many such results as were observed would be. expected by chance), and for some diagnostic groups no risk factors at all emerged.

The excess of illnesses over 6 months of age among the cases is explained by the highly significant case excess reporting symptoms, signs and ill-defined conditions (ICD9 780-799). Detailed examination showed that no individual diagnostic group had a significant excess of non-specific conditions. The excess was not related to age at onset and affected children with solid tumours and leukaemia equally.

One aspect of IRESCC was the inability to control for bias in reporting by case parents. Although hospital control parents had previously had the experience of relating their child's past medical history on admission to hospital, case parents had probably considered their child's past experiences more extensively in the search for the cause of their child's cancer. Over-reporting of apparently trivial conditions in cases may have occurred and nonspecific signs and symptoms given greater significance. Alternatively, because of the difficulty of determining the precise time of onset for a particularly malignancy, the excess of symptoms and signs in the case children could be genuine manifestations of their disease. Careful perusal of the clinical histories of some of the case children indicates that symptoms relating to the malignancy could be present months or even years before diagnosis. This was particularly evident for children with brain tumours.

Overall, fewer cases had suffered from contact dermatitis and other eczema (ICD9 692.0-692.9, table 3). More particularly, although Hodgkin's disease in adults is reported to be associated with atopic dermatitis ${ }^{20}$ and eczema/dermatitis, ${ }^{21}$ a history of contact dermatitis and other eczema was reported in equal (and very small) proportions of Hodgkin's disease cases and controls in the present study $(2 \mathrm{C}, 1$ GPC, 3 HC). Atopic dermatitis (ICD9 691.0-691.9) was reported less frequently in children with Hodgkin's disease under 6 months (2 C, $3 \mathrm{GPC}, 4 \mathrm{HC})$ or over 6 months (1 C, 2 GPC, $3 \mathrm{HC}$ ). 
An association between infectious mononucleosis and Hodgkin's disease has also been described ${ }^{22}$ and confirmed for young adult males. ${ }^{21}$ While proportionately more cases than controls in IRESCC had suffered from this infection, numbers were too small for analysis (4 C, $1 \mathrm{GPC}, 3 \mathrm{HC}$ ). Three of the four reported cases however fell in the leukaemia/ lymphoma group (one ALL, one other leukaemia, one Hodgkin's disease). Evidence for the finding that children who have undergone tonsillectomy are at excess risk of subsequently developing Hodgkin's disease $^{10}$ could not be evaluated from this study.

Detailed analysis of IRESCC children with leukaemia/lymphoma has revealed an excess of reported viral illnesses under 6 months of age. ${ }^{19}$ This effect has been examined for all cases in IRESCC and is non-significant overall $(12 \mathrm{C}, 4 \mathrm{GPC}, 11 \mathrm{HC} ; \mathrm{RR}=$ $1 \cdot 61,95 \%$ CI $0.70-3 \cdot 67, \mathrm{p}=0 \cdot 3$ ). There was also an excess of confirmed upper respiratory tract infections over 6 months of age in IRESCC children. These findings are in contrast to those of another investigation which found fewer infectious illnesses in the first year of life in children with leukaemia. ${ }^{9}$

Previous medication appeared to have little association with childhood cancer and the effect of previous therapeutic irradiation could not be assessed from this study.

The finding that children who had received none of the standard immunisations were at significantly higher risk of developing cancer is potentially of great interest and confirms the results of another study which has addressed this issue. ${ }^{23}$ The problems of interpreting immunisation history as given by parents are enormous. Precise dates were not recorded at interview and a tendency to over-record control immunisations may have resulted from the natural time lag between case and control interviews. In addition, for younger children, controls were up to 6 months older than the cases. This effect could be confounded by the problem of defining the onset date for the case child. Ill-health caused by an undiagnosed malignancy could in itself act as a contraindication to immunisation, further reducing the numbers of cases immunised compared with their controls. Nevertheless after eliminating from the analysis all children under 2 years of age at diagnosis, a highly significant case deficit still remained. The significance of these findings in relation to the child's developing immune system and susceptibility to early infections is not clear, but further more detailed studies may yield interesting and important results in relation to current immunisation programmes and their benefits.

In this study we have examined a wide range of factors in the child's past medical history in relation to the development of childhood malignancy. However, because the study was based upon reported events and their subsequent confirmation from medical records, the significance of some factors which may be relevant to the problem could not be examined on a casecontrol basis. Because of the nature of their illness, children with a malignancy are extensively investigated at the time of diagnosis, thus revealing less obvious aspects of their medical history or status. The same investigations have not taken place in most controls, hence the frequency of such events is not known and valid comparisons of this kind of variable cannot be made. Examples of this would be the incidental finding that a child with ALL and congenital cytomegalovirus infection also had a balanced chromosome translocation and that another child with Down's syndrome and ALL also had the same infection. Similarly because of the coding conventions adopted and the need for some simplification of the data, short courses of drugs given after the first month of life were not coded. Hence the overall significance of the use of chloramphenicol in IRESCC children cannot be assessed in the light of a recent report that there is a significantly elevated risk of ALL in children treated with chloramphenical for infectious disorders. ${ }^{24}$ However, two of the three children in IRESCC who had had bacterial meningitis had been treated with chloramphenicol. Both these children had ALL.

The overwhelming impression from the results presented here is of a lack of association between medical events in childhood and the subsequent development of childhood cancer. A very large number of comparisons were made, but few significant associations emerged and it is likely that some of these were due to chance. Where significant relative risks did emerge these were often restricted to specific diagnostic groups and although the study included a large number of cases overall, numbers in some diagnostic groups were quite small. Hence few findings could be applied to the generality of childhood cancer. The most important finding could be the apparent protective effect of immunisation. More detailed analyses of the results by diagnostic group may reveal more specific aetiological agents. Alternatively, the findings may show that environmental factors of the kind which we examined are lacking major aetiological importance. Genetic predisposition may have greater influence, or specific genetic-environmental interactions in certain children may not be detected by the present analysis. Further multi-variate analyses taking into account family history of malignancy and other factors, possibly prenatal, would be necessary to throw light on these issues. 
We thank the parents of the children included in the study and the many general practitioners, consultants and nurses in the three regions who assisted us; also the Cancer Research Campaign, the Leukaemia Research Fund, the Department of Health and Social Security, the Scottish Home and Health Department, the Special Trustees for the former United Birmingham Hospitals Trust Funds, and the Special Trustees of Leeds Western Health Authority for financial support. We thank Dr H G Frank, Dr E Hill and many other paediatricians, surgeons and radiotherapists whose patients were included; and the medical records officers and Cancer Registries in the three regions for their help. We thank Dr D I K Evans, Dr F G H Hill and Dr M F Greaves for haematological confirmation of diagnoses; Office of Population Censuses and Surveys for access to death certificates; Mrs P Brown, Mr R W Boyko, Mrs C Christmas, Mrs E Dale, Mrs P Dilworth, Mrs J Hogg, Miss C Kite, Miss P M Landells, Mrs A Mainwaring, Miss G Mason, Mrs J Olden, Mrs E M Roberts, Dr M Potok, Mrs S Warner and Mr D Winterburn for secretarial, statistical and computing assistance; Rank Xerox for photocopying; Bell \& Howell for the use of a microfilming camera; Systime Ltd for the gift of a computer and the University of Leeds for the use of the Amdahl computer.

Correspondence to Dr A L Hartley, Department of Epidemiology and Social Oncology, Christie Hospital and Holt Radium Institute, Manchester M20 9BX.

\section{References}

${ }^{1}$ Bithell JF, Stewart AM. Pre-natal irradiation and childhood malignancy: A review of British data from the Oxford survey. Br J Cancer 1975; 31: 271-87.

2 Hopton PA, McKinney PA, Cartwright RA, et al. X-rays in pregnancy and the risk of childhood cancer. Lancet 1985; ii: 773 .

${ }^{3}$ Herbst AL, Ulfelder H, Poskanzer DC. Adenocarcinoma of the vagina. Association of maternal stilbestrol therapy with tumour appearance in young women. $N$ Eng $J$ Med 1971; 284: 878-81.

${ }^{4}$ Pendergrass TW, Hanson JW. Fetal hydantoin syndrome and neuroblastoma. Lancet 1976; ii: 150.

${ }^{5}$ Otten J, Smets R, De Jager R, Gerard A, Maurus R. Hepatoblastoma in an infant after contraceptive intake during pregnancy. $N$ Eng $J$ Med 1977; 297: 222.

6 Arundel SE, Kinnier-Wilson LM. Parental occupations and cancer: a review of the literature. $J$ Epidemiol Community Health 1986; 40: 30-6.
${ }^{7}$ Birch JM. Genetic determinants of cancer in man. In: Waring MJ, Ponder B, eds. Biology of carcinogenesis Lancaster: MTP Press Ltd, 1987.

${ }^{8}$ de-Thé G, Geser A, Day NE, et al. Epidemiological evidence for causal relationship between Epstein-Barr virus and Burkitt's lymphoma from Ugandan prospective study. Nature 1978; 274: 756-61.

${ }^{9}$ Van Steensel-Moll HA, Valkenburg HA, Van Zanen GE. Childhood leukaemia and infectious diseases in the first year of life: A register-based case-control study. Am J Epidemiol 1986; 124: 590-4.

10 Vianna NJ, Lawrence CE, Davies JNP, Arbuckle J, Harris S, Marani W, Wilkinson J. Tonsillectomy and childhood Hodgkin's disease. Lancet 1980; ii: 338-40.

${ }^{11}$ Birch JM, Mann JR, Cartwright RA, et al. The InterRegional Epidemiological Study of Childhood Cancer (IRESCC). Study design, control selection and data collection. Br J Cancer 1985; 52: 915-22.

12 World Health Organisation. International classification of diseases. 9th revision, 1975. Geneva: WHO, 1978.

${ }^{13}$ SPSS version X user's guide. New York: McGraw-Hill, 1985.

14 Breslow NE, Day NE. Statistical methods in cancer research. Vol I. The analysis of case-control studies. IARC Scientific Publications No 32. Lyon: International Agency for Research on Cancer, 1980.

15 Bader JL, Meadows AT, Zimmerman LE, Rorke LB, Voute PA, Champion LAA, Miller RW. Bilateral retinoblastoma with ectopic intracranial retinoblastoma: Trilateral retinoblastoma. Cancer Genet Cytogenet 1982; 5: 203-13.

${ }^{16}$ Fasal E, Jackson EW, Klauber MR. Birth characteristics and leukaemia in childhood. J Natl Cancer Inst 1971; 47: 501-9.

${ }^{17}$ Daling JR, Starzyk P, Olshan AF, Weiss NS. Birth weight and incidence of childhood cancer. $J$ Natl Cancer Inst 1984; 72: 1039-41.

${ }^{18}$ Eisenberg DE, Sorahan T. Birth weight and childhood cancer deaths. J Natl Cancer Inst 1987; 78: 1095-100.

${ }^{19}$ McKinney PA, Cartwright RA, Saiu JMT, et al. The inter-regional epidemiological study of childhood cancer (IRESCC): a case control study of aetiological factors in leukaemia and lymphoma. Arch Dis Child 1987; 62: 279-87.

${ }^{20}$ Winkelmann RK, Rajka G. Atopic dermatitis and Hodgkin's disease. Acta Dermatol 1982; 63: 176-7.

${ }^{21}$ Bernard SM, Cartwright RA, Darwin CM, Richards IDG, Roberts B, O'Brien C, Bird CC. Hodgkin's disease: Case control epidemiological study in Yorkshire. $\mathrm{Br} J$ Cancer 1987; 55: 85-90.

22 Munoz N, Davidson RJL, Witthof B, Ericsson JE, de-Thé G. Infectious mononucleosis and Hodgkin's disease. Int $J$ Cancer 1978; 22: 10-3.

${ }^{23}$ Kneale GW, Stewart AM, Kinnier Wilson LM. Immunizations against infectious diseases and childhood cancers. Cancer Immunol Immunotherapy 1986; 21: 129-32.

${ }^{24}$ Shu XO, Linet MS, Gao RN, Gao YT, Brinton LA, Jin F, Fraumeni JF Jr. Chloramphenicol use and childhood leukaemia in Shanghai. Lancet 1987; ii: 934-7.

Accepted for publication May 1988 